RESEARCH PAPER

\title{
International trade agreements: a threat to tobacco control policy
}

\author{
E R Shaffer, J E Brenner, T P Houston
}

Tobacco Control 2005;14(Suppl II):ii19-ii25. doi: 10.1136/tc.2004.007930

International covenants establish a role for governments in ensuring the conditions for human health and wellbeing, which has been recognised as a central human right. International trade agreements, conversely, prioritise the rights of corporations over health and human rights. International trade agreements are threatening existing tobacco control policies and restrict the possibility of implementing new controls. This situation is unrecognised by many tobacco control advocates in signatory nations, especially those in developing countries. Recent agreements on eliminating various trade restrictions, including those on tobacco, have expanded far beyond simply international movement of goods to include internal tobacco distribution regulations and intellectual property rules regulating advertising and labelling. Our analysis shows that to the extent trade agreements protect the tobacco industry, in itself a deadly enterprise, they erode human rights principles and contribute to ill health. The tobacco industry has used trade policy to undermine effective barriers to tobacco importation. Trade negotiations provide an unwarranted opportunity for the tobacco industry to assert its interests without public scrutiny. Trade agreements provide the industry with additional tools to obstruct control policies in both developed and developing countries and at every level. The health community should become involved in reversing these trends, and help promote additional measures to protect public health.

See end of article for authors' affiliations

Correspondence to: Ellen R Shaffer, PhD MPH, Center for Policy Analysis on Trade and Health, 98 Seal Rock Drive, San Francisco, CA 94121 USA; ershaffer@cpath.org occur in low and middle income nations, placing a huge strain on those health care systems. Worldwide, tobacco use is more prevalent among the poor, the uneducated, and those least informed about the effects of tobacco use.

The wide range of human rights includes economic sufficiency, but also the right to health and protection from harm. International trade agreements set and enforce particular economic relationships among countries. In doing so, they prioritise the rights of corporations over health and human rights. Some argue that this wellbeing in the long term, by removing regulatory constraints on corporate activity and thereby creating economic growth. At its furthest extension, the argument contends that greater personal freedom to consume a wide array of products is a component of political freedom, and therefore enhances human rights. ${ }^{1}$ Even from this perspective, it is important to preserve government policies and actions that guard populations from preventable life threatening hazards. Trade agreements typically recognise nations' rights to protect national security, and to control air space, for example. Many control advocates believe that tobacco should be treated as a hazardous substance, rather than as an ordinary product. To the extent that trade agreements promote tobacco use and protect the tobacco industry, they challenge human rights and contribute to ill health.

Individuals and their democratically chosen representatives also have the right to participate in decisions regarding their health. Trade negotiations and dispute proceedings are generally closed to the public, public health officials, and most elected representatives.

We review examples of international agreements that establish the right to health, discuss how trade rules work and how they have operated in the past to undermine tobacco controls, and illuminate emerging rules and decisions that directly threaten states' abilities to protect the right to health. We argue that health should take priority over the right of corporations to compete in markets generally, and particularly in the case of tobacco products and services. Trade strategies can provide the opportunity to legitimise tobacco products. We note that confidential trade processes can undermine the right to popular participation in decision making. Finally, we conclude that rights based arguments offer powerful tools for tobacco control and in countering provisions of trade agreements that would neutralise measures to protect the public's health. approach will advance people's health and
Abbreviations: CAFTA, Central America Free Trade Agreement; FIDH, International Federation for Human Rights; FCTC, Framework Convention on Tobacco Control; FTAA, Free Trade Area of the Americas; GATS, General Agreement on Trade in Services; GATT, General Agreement on Tariffs and Trade; ISO, International Standards Organization; NAFTA, North American Free Trade Agreement; SPS, Agreement on Sanitary and Phytosanitary Standards (SPS); TBT, Technical Barriers to Trade; TRIPS, Agreement on Trade-Related Aspects of Intellectual Property; UDHR, Universal Declaration of Human Rights; USCEA, US Cigarette Export Association; WTO, World Trade Organization 


\section{THE RIGHT TO HEALTH}

Several international agreements assert the right to health and protection from harm. During the 1993 Vienna Human Rights Conference, 171 governments arrived at the consensus that "the promotion and protection of human rights is a matter of priority for the international community". ${ }^{2}$ Health is recognised as a central human right, and a universal aspiration of all people. Protection from factors that adversely impact the health of individuals and populations is basic to human rights. The International Covenant on Economic, Social and Cultural Rights establishes a role for governments in ensuring the conditions for health and wellbeing. ${ }^{3}$ At the World Summit for Social Development convened in Geneva in 2002, national leaders pledged to protect health, and to "give the highest priority to the promotion of social progress, justice, and the betterment of the human condition".

Children are particularly adversely affected by tobacco use, including the effects of maternal smoking on pregnancy and the effects of passive smoking. Adult smoking and tobacco advertising lead to youthful initiation of tobacco use and to uninformed "choices" that are ultimately deadly.

The United Nations Convention on the Rights of the Child, adopted in 1989, obligates its 191 signatories to binding international obligations that include "the right to life, survival, and development". Article 3 of the Convention states that "in all actions concerning children, whether undertaken by...administrative authorities or legislative bodies, the best interests of the child shall be a primary consideration". This means that states must refrain from adopting actions that could interfere with children's human rights. The Committee on the Rights of the Child has clearly identified the issue of tobacco consumption as coming within the scope of the Convention. Because of the enormous potential harm to children from tobacco use and exposure, states are obligated to take all necessary legislative and regulatory measures to protect children from tobacco and ensure that the interests of children take precedence over those of the tobacco industry. ${ }^{4}$

\section{OVERVIEW OF TRADE AGREEMENTS: HISTORY AND EMERGENCE OF THE WORLD TRADE ORGANIZATION}

The Bretton Woods accords marked a milestone in modern global economic policy. The accords sought to stabilise the post-second world war economies of Western Europe. The process established the World Bank and the International Monetary Fund, and set guidelines for economic indicators such as levels of debt, and interest rates. The founding countries did not agree on creating a similar formal institution to regulate international trade. Instead, they signed on to the General Agreement on Tariffs and Trade (GATT), which established the framework for subsequent international trade agreements.

Trade agreements bind nations that sign them to rules intended to promote the free flow of goods and reduce barriers to cross border trade. Trade barriers may be financial, such as tariffs that make foreign goods more expensive, therefore protecting domestic companies but harming foreign corporations. Laws and regulations that require products and services to meet particular standards can also be considered "non-tariff" trade barriers.

The GATT established key principles now enforced by the World Trade Organization (WTO). One important principle is non-discrimination between a country's domestically produced goods and foreign goods, and also among all foreign goods. The GATT reduced tariffs and other barriers to international trade such as import quotas, and imposed requirements that foreign and domestic goods be treated equally. Another principle was the harmonisation of stan- dards internationally, which may establish a ceiling for regulatory requirements, rather than a floor. Domestic laws that exceed these standards could be subject to challenge under international trade rules.

During the 1980s, the global economy became more closely integrated. Technological changes in communication and transportation accelerated exchanges in goods and services. Services such as banking and finance, telecommunications, construction, and health care accounted for an increasing share of developed countries' economic activity. The axioms of international trade policy mirrored the goals of some developed nations to reduce the role of governments generally. These goals included restricting their ability to regulate; privatising ownership and production of services and goods; reducing public funding generally and subsidies to private corporations in particular; and decentralising administrative and financial procedures to the state and local level, thus weakening central control at the national level. These axioms were reflected in proposals to include new realms of commerce and social policy, such as services, agriculture, and investments, within the remote jurisdiction of international trade agreements.

The WTO was formally established in 1995. The WTO introduced several new agreements, which are binding on all 148 member nations. The agreements impose strict rules related to government regulation, taxation, purchasing, and economic development policies, which are regarded as nontariff barriers to trade. Trade rules require that nations must use the least trade restrictive means of achieving their policy goals, and those domestic regulations can be no more burdensome to trade than necessary. Trade agreements can generally supersede any level of local, state, or national decision making, once a country has signed on.

\section{TRADE AGREEMENTS: RATIONALE AND HUMAN RIGHTS CONCERNS}

Critics contend that WTO agreements undermine the obligations to health presented by international human rights covenants, and present obstacles to government action that could fulfil those obligations. Proponents argue that encouraging trade increases wealth and reduces poverty. If true, it could be argued that trade therefore creates conditions for the enjoyment of human rights. Government regulations that would impede trade might be justifiably overridden. The evidence is equivocal at best. A review of the economic benefits of the North American Free Trade Agreement (NAFTA) after 10 years found little net benefit to the USA, when other trends were factored in, and major deficits for Mexico. ${ }^{5}$

A growing number of economists assert that poverty eradication and related improvements in health depend on a range of policies that offer social support as well as holding governments and corporations accountable. Trade policies that give priority in virtually all circumstances to the rights of corporations to enter and exit markets fail to give proper consideration to government measures that directly protect health, and that therefore also contribute to sustainable economic development and human rights.

Economic growth and development depend on a complex array of factors, and countries have experienced success with a mix of policies that encourage cross border trade, and those that focus on building domestic capacities and resources. Government policies that favour certain industries or companies over others, domestically or across borders, may suppress competition, or may contribute to a successful strategy for economic development. However, the present approach conflates and proposes to discard a wide array of government measures. Many government activities are widely credited with contributing both to the wellbeing and 
protection of populations, and to economic development These range from regulations that require corporate accountability, to measures that directly protect and improve the health of individuals and communities. These measures and policies are equally at risk under the terms of trade agreements.

\section{ENFORCING TRADE RULES}

WTO enforcement mechanisms are powerful and effective. When nations charge each other with violations of trade rules, disputes are adjudicated by an appointed tribunal of trade experts, who are authorised to impose substantial financial penalties, trade sanctions and product boycotts on the losing party. The proceedings are closed to the public and cannot be appealed outside of the trade tribunal system.

In the past, trade negotiators have sought confidentiality in part to protect sensitive information about countries' prices and other negotiating positions. As agreements increasingly address critical social policies, policymakers have called for greater transparency in the proceedings.

Regional trade agreements such as NAFTA, and bilateral (country-to-country) agreements, include enforcement provisions that allow even greater restrictions on government authority than WTO rules. These agreements have further weakened national regulations. Chapter 11 of NAFTA, which covers Canada, the USA, and Mexico, included the first investors' rights clause in a regional agreement. This allows corporations to challenge countries directly for trade violations, without going through their own national governments. In a pending NAFTA case, a Canadian company named Methanex has filed a trade dispute against the USA to delay the state of California from removing a harmful gasoline additive, MTBE, which the company helps to produce. Methanex has demanded $\$ 980$ million to compensate for the loss of current and prospective profits. This investors' rights provision has since been proposed or adopted in other US bilateral and regional agreements.

\section{INTERNATIONAL TRADE AGREEMENTS AND TOBACCO CONTROL}

The process of removing government restrictions on cross border commerce through trade agreements is known as liberalisation. A review of the implications of trade agreements for tobacco control in 2000, by Chaloupka and Nair, noted that liberalisation of trade in tobacco opens countries to competition from lower priced foreign tobacco products, leading to lower prices in the importing country. Liberalisation, and resulting lower prices, are therefore associated with greater tobacco use. ${ }^{6}$ The authors recommended increased national level activity to control tobacco use, rather than proactively encouraging restrictions on trade. This strategy assumes that trade rules only penalise government activities that discriminate among products from different countries. National laws and regulations that control tobacco use, but do not provide an advantage to national tobacco products compared with imported ones, would presumably be safe from trade challenges.

However, trade negotiations and rules undermine national level tobacco regulations in two ways. National rules that restrict international trade in tobacco, including those that discriminate among countries, can protect populations in low and middle income countries that are targets for tobacco industries based in high income nations such as the USA, where tobacco use is shrinking. However, countries can be heavily pressured to consent to liberalising trade in tobacco as a condition of access to other promised trade related economic benefits. Therefore, opposing greater liberalisation of trade in tobacco is an important defence of the human right to health.
In addition, trade rules increasingly can challenge national laws and regulations that protect health, even if they are applied equally across countries, and do not discriminate among them. The most recent generation of trade agreements and trade rulings present additional obstacles to governments that would protect the right to health from the tobacco trade, as described in the following section.

The success of the Framework Convention on Tobacco Control (FCTC) provides encouragement to positive proactive tobacco control strategies. It could offer a potential counterweight and an alternative to international trade agreements. It is notable, however, that control advocates did not prevail in including language in the FCTC stating that it would take priority over trade agreements.

\section{TRADE RULES IMPINGE ON HEALTH}

The GATT provides an exception to its extensive rules governing trade, allowing nations to adopt and enforce measures necessary to protect human, animal, or plant life or health. Measures include laws, regulations, standards, and other actions. This exception, in GATT Article XX (b), however, requires that such measures cannot arbitrarily or unjustifiably discriminate between countries or be a disguised restriction on international trade. Nations have brought challenges before trade tribunals claiming that public health measures violate trade rules. These challenges to public health measures have been successful in almost all cases. The burden is on the nation attempting to implement the public health measure to prove that the public health exception in GATT is applicable. To do so, a nation has to meet a two tiered test: (1) show that the health or environmental measure is necessary-that is, that it is effective and that no less trade restrictive measures to achieve the same public health purpose were available; and (2) if proven to be necessary, show that the proposed public health measure does not constitute a "disguised restriction on international trade" or "arbitrary or unjustifiable discrimination". If the effect is discriminatory, the measure may be rejected even if it is shown to be "necessary" to protect public health. ${ }^{78}$ For example, a nation that imposes restrictions on tobacco imports may be challenged to prove that import restrictions on tobacco products are "necessary" for tobacco control, and that import restrictions are less restrictive on trade than alternative health protections-for example, consumer health warnings. ${ }^{89}$ The health protective alternatives can be hypothetical, and need not be demonstrably effective or politically feasible.

The General Agreement on Trade in Services (GATS) is a WTO agreement that extends trade rules to services, including advertising, packaging, retailing, and distribution, all of which are activities that could apply to trade in tobacco, as well as to banking, telecommunications, health care, and education. The GATS requires that domestic regulations that set rules for licensing and qualifications, and technical standards, must be no more burdensome than necessary to ensure the quality of a service. While elements of the domestic regulation rule remain under negotiation at the WTO level, its proposed language is being adopted in some regional and bilateral agreements. Measures that apply standards to foreign corporations, even if they apply equally to domestic ones, can be subject to challenge under GATS.

A recent trade dispute decision under GATS ruled that US federal and state prohibitions on internet gambling violated US trade commitments. Under this "market access" commitment, the USA had agreed not to limit the number or type of service providers engaged in gambling. Many states had enacted measures to limit or prohibit internet gambling, in response to concerns about organised crime, money laundering, gambling by minors, and the effect of gambling on public 
morals generally. ${ }^{10}$ "United States-Measures Affecting the Cross-border Supply of Gambling and Betting Services" ruled in favour of Antigua's complaint against the USA.

In addition, some of the investment rules that were proposed in the defeated Multilateral Agreement on Investment are reappearing in GATS and other agreements. These agreements greatly expand the definition of expropriation of property under US law, suggesting that measures that reduce a business' operations or profits constitute a trade violation, even if doing so protects public health.

Other WTO agreements with important implications for tobacco control include the following:

- Agreement on Trade-Related Aspects of Intellectual Property (TRIPS) governs labelling and product/content disclosure. TRIPS protections for trademark holders (such as tobacco brand names) have far reaching public health implications. It states: "The use of a trademark in the course of trade shall not be unjustifiably encumbered by special requirements, such as use with another trademark, use in a special form or use in a manner detrimental to its capability to distinguish the goods or services of one undertaking from those of other undertakings. ${ }^{\prime 8}$ The novel warnings on cigarette packs in Thailand, Canada, and Brazil could be challenged under this rule.

- Agreement on Sanitary and Phytosanitary Standards (SPS) reduces barriers to trade that derive from governments' regulations and laws designed to protect the health of humans, animals, and plants. ${ }^{11}$

- Technical Barriers to Trade (TBT) encourages the use of international standards as the basis for technical regulations that affect trade. Internationally recognised standards, such as those of the International Standards Organization (ISO), are presumed not be unduly burdensome to trade; unlike SPS, the TBT does not require measures to be scientifically justified. A possible benefit of TBT is that if tobacco control measures become recognised as international standards (for example, through FCTC), these measures may enjoy the presumption that they are "necessary" and "least restrictive" under the TBT agreement. In the absence of internationally recognised tobacco control standards, tobacco control measures are subject to challenge under language comparable to GATT Art. $\mathrm{XX}(\mathrm{b}) .{ }^{12}$

\section{PAST TRADE DISPUTES AND TOBACCO}

Past trade disputes have threatened, chilled, or overturned tobacco control measures:

- The US Cigarette Export Association (USCEA), an association of US tobacco companies, successfully utilised the 1984 amendments to Section 301 of the 1974 Trade Act to enlist cooperation of the executive branch of the US government in threatening trade sanctions against countries in Asia where quotas, high tariffs, high retail taxes, and advertising and distribution restrictions on tobacco were alleged to unfairly limit the markets for US tobacco products. ${ }^{13}$ The challenge was especially harmful to youth and women, who had historically low rates of cigarette smoking. A Goverment Accountability Office study showed that smoking among South Korean male teens rose from $18.4 \%$ to $29.8 \%$ in a single year, and quintupled among teen women, rising from 1.6 to $8.7 \% .^{14}$

- In 1990, Thailand's restriction of the importation of cigarettes was found unjustified and in violation of GATT, even though the trade panel recognised that chemicals and other additives in US cigarettes may have been more harmful than those in Thai cigarettes. ${ }^{89}$
- Canada withdrew its intent to legislate "plain" packaging for cigarettes when Philip Morris threatened to launch a trade dispute in 1994, demanding millions for "expropriation" of their intellectual property-that is, their trademark-if Canada proceeded with its plans. ${ }^{8}$

- Philip Morris threatened Canada with a challenge under NAFTA if it were to go forward with a proposal to ban misleading descriptors ("light," "mild," "low"). Japan Tobacco protested a European ban on these descriptors as an infringement of trademark rights, joining a case filed by British American Tobacco (BAT) and Imperial Tobacco in the European Court of Justice. The Court rejected JT's claim, but specified that the decision was not a determination of the TRIPS legality related to the ban on tobacco descriptors.

\section{NEW AND CURRENTLY NEGOTIATED REGIONAL AND BI-NATIONAL AGREEMENTS}

After serious disagreements among nations surfaced within the WTO in 2003, the USA turned to increasing its bilateral and regional negotiations with other countries, where the USA generally has superior economic and political bargaining leverage. These new agreements continue to pose threats to tobacco control and human rights.

In response to the USA's past use of trade agreements to force open East Asian markets to tobacco, the Clinton Administration issued an Executive Order stating it would no longer seek tariff reductions on leaf tobacco or tobacco products. This position has been partially reversed by the present administration, which is now seeking market access for leaf tobacco in all agreements. The Doggett Amendment to the Foreign Service Act, passed in the 1990s, prohibits certain US agencies from promoting tobacco exports, but there is an important exception: they can intervene when there are concerns about equal treatment of US products or violations of existing agreements. Unequal treatment is the basis of most trade disputes.

The US-Singapore Free Trade Agreement, approved in 2003, eliminated tobacco tariffs for Singapore. This free trade agreement includes NAFTA-like provisions that give investors, including tobacco companies, standing to challenge governmental regulations at the local, state, and national levels directly and seek compensation for profits lost due to rules that do not comply with strict investment obligations.

Under the pending Central America Free Trade Agreement (CAFTA), more than $80 \%$ of US exports to consumers and industrial products to Central America will be duty-free immediately upon entry into force of the agreement, and all remaining tariffs will be eliminated within 10 years. The agreement applies to advertising, intellectual property, and services.

The USA is also negotiating the Free Trade Area of the Americas (FTAA), which would extend NAFTA-like trade rules to the 34 nations of the western hemisphere, excluding Cuba. The FTAA includes an investors' rights provision. Pending negotiations were scheduled to conclude early in 2005, but have been delayed by disagreements among the parties.

\section{NAFTA CHALLENGE TO THE MASTER SETTLEMENT AGREEMENT}

Trade dispute decisions have both undermined public health protections, including those related to tobacco control, and had a chilling effect on proposed regulations. By chilling protections, they thus interfere with the human right to democratic participation in the political process.

The most recent tobacco related dispute illustrates the broad scope for challenges to local, state, and national 
sovereignty. Grand River Enterprises Six Nations, a relatively small tobacco company based in Ontario, claims that the multi-state Master Settlement Agreement that settled a lawsuit between 46 US states and major tobacco companies infringes on its rights under NAFTA. The 1998 settlement imposed a schedule of fines on the companies involved. The states also decided to apply the terms of the settlement agreement to all non-defendant tobacco companies. Nondefendant firms could choose to opt out of the settlement, in which case they were required to contribute funds to state escrow accounts. Grand River claims in a Chapter 11 NAFTA charge that the requirement to pay into the state escrow account is an expropriation of their investment, that the major defendant tobacco companies conspired to gain more favourable terms than non-defendants in order to drive them out of business, and that other foreign firms (in businesses other than tobacco) are not required to maintain an escrow account while doing business in the USA. ${ }^{15}$ The charge is being heard, although the terms of the agreement apply equally to all non-defendant tobacco firms in the USA and abroad.

\section{TRADE AGREEMENT IMPACTS ON TOBACCO CONTROL: PROSPECTIVE}

Prospectively, trade agreements enable the industry to challenge a wide range of tobacco control measures:

- Tobacco tariffs-Finished tobacco products are exported primarily by companies based in developed countries. Tariffs imposed by developing countries raise the price on imported tobacco and tobacco products, thereby discouraging tobacco use. Tobacco tariffs may be eliminated, particularly in the course of bilateral trade negotiations in which developed countries have greater economic and political power. As noted above, Singapore eliminated tobacco tariffs in its 2003 agreement with the USA. Tariffs can also be challenged as discriminatory and restrictive trade barriers. While tariffs in the USA are already low and imports account for a very small fraction of the total market, higher tariffs might have a dramatic effect in niche markets such as bidis and kretek cigarettes, which have grown in popularity among American youth. ${ }^{9}$

- Reducing exposure to secondhand smoke-Clean indoor air rules, including banning smoking in restaurants and bars, could face challenge as barriers to trade since these policies decrease cigarette consumption, and company profits. $^{8}$

- Ingredient disclosure and warning labels-Under investor rights provisions, private corporations could sue for "expropriation" of property as a result of regulations on ingredient disclosure and warning labels. Tobacco companies have argued that such information is protected from disclosure to consumers by TRIPS. Philip Morris threatened to lodge a trade protest over Thailand's proposed warning labels. ${ }^{12}$

- Controlling sale and distribution of tobacco products -Wholesale and retail licensing, controls on vending machines, and restrictions on sales to children could be subject to challenge under rules governing distribution services in GATS and other trade agreements. ${ }^{8}$

- Cigarette content regulation-Laws and regulations to enact tobacco control affecting cigarette content regulation, including fire-safe cigarettes, are subject to challenge under the Technical Barriers to Trade agreement and other WTO provisions. Consumer warnings could be required as a substitute for product regulation as they are less restrictive to trade, but they are also less effective tobacco control measures. ${ }^{8}$

- Advertising, promotion, sponsorship, and marketing restrictions-Partial bans of cigarette advertising could be challenged as trade violations under GATS rules if a country agrees to be covered by GATS rules affecting advertising. The 1990 GATT decision upholding Thailand's ban on cigarette advertising predated GATS and did not address newer requirements to harmonise with international standards. ${ }^{8}$

- Non-profit voluntary agencies-GATS provides no preferential treatment for voluntary agencies over commercial service providers. Commercial interests may challenge and demand access to any preferences, including subsidies, that are made available to the non-profit sector for health promotion, education, or smoking cessation programmes. For example, a foreign commercial enterprise might challenge a local tobacco control association as a provider of smoking cessation services. ${ }^{8}$

\section{TOBACCO'S TRADE STRATEGIES: EXPANDING MARKETS, LEGITIMISING TOBACCO PRODUCTS}

International trade agreements provide several important opportunities for the tobacco industry to maintain its influence. First, tobacco control advocates claim that tobacco should be treated as a hazardous product. The industry, however, pursues strategies to be treated similarly to any other legitimate product. In the USA, where state and national level controls are among the strongest in the world, the industry protects its legitimate image, in order both to continue marketing in the USA and to expand sales internationally. The US Trade Representative includes tobacco in its consideration of agricultural products. Tobacco is treated as a legitimate product rather than a hazardous substance under trade rules, offering credibility and standing to the tobacco industry.

In addition, because trade negotiations are conducted secretly, with special confidential access to government negotiators by designated industry officials, the tobacco industry has the opportunity to win policy victories out of public view. Further, some entities other than the tobacco industry may take a more visible role in certain trade disputes. For example, duty-free stores could lead the opposition to proposed bans on cigarettes in those stores, providing allies for the industry and removing it from the central spotlight.

The tobacco industry's opposition to the FCTC has been publicly reported. However, there has been little notice of the industry's support for trade agreements, and little association of trade negotiations with the industry. Nevertheless, support for trade agreements is clearly among industry strategies designed to expand markets and limit tobacco control:

\begin{abstract}
"Philip Morris strongly supports NAFTA and also supports the Uruguay Round process [to establish the WTO]...[A]rtificial trade barriers have kept us out of some countries. The removal of trade barriers will provide us with expanded market opportunities. We are well positioned to take advantage of the new opportunities that the removal of trade barriers will offer us. I see both the NAFTA and the Uruguay Round as real 'winners' as far as Philip Morris is concerned."16
\end{abstract}

\section{TRADE AND THE RIGHT TO PARTICIPATION}

The International Covenant on Economic, Social and Cultural Rights guarantees that people have the right to popular participation in decisions regarding their health, and recourse in the event of violations. ${ }^{17}$ As noted above, trade agreements 
are negotiated largely in secret, and dispute resolution proceedings also are not transparent. At the national level, health ministries are often excluded from trade negotiations. There is no official role in the WTO for international health agencies such as the World Health Organization.

Official advisory committees to the US Trade Representative, the executive branch agency that leads trade negotiations, include no representatives of public health or tobacco control experts. On the other hand, the tobacco industry is widely represented, serving on Trade Advisory Committees for Tobacco, Cotton and Peanuts, and for Consumer Goods. The chair of the Consumer Goods Committee is a vice president of the tobacco company Altria. A report by the Government Accountability Office found that Advisory Committee members are highly satisfied with their ability to influence trade policy. ${ }^{18}$

Members of the Agricultural Technical Advisory Committee to the US Trade Representative stated that the proposed US trade agreement with Singapore appropriately covered all agricultural products, including tobacco. The committee included the Leaf Tobacco Exporters Association, Flue-Cured Tobacco Coop Stabilization, Altria Corporate Services, Inc, and Tobacco Associates, Inc. ${ }^{19}$ As noted above, the 2003 agreement eliminated tobacco tariffs in Singapore.

\section{THE RIGHT TO WEALTH VERSUS THE RIGHT TO HEALTH}

Critics of trade policy regarding public health can disagree on the general benefits of trade agreements. The National Conference of State Legislatures, for example, reported one member's support for trade agreements that generate jobs and economic growth, while being critical of the GATS decision on internet gambling, and its infringement on public officials' authority. ${ }^{10}$

There should be little question, however, that routinely liberalising trade in tobacco and undermining states' ability to implement tobacco control measures, in non-transparent, undemocratic settings, is not a necessary trade-off for economic growth and development. Other international agreements address specific concerns about hundreds of hazardous products including small arms, landmines, narcotic drugs and psychotropic substances, ozone depleting chemicals, hazardous waste, persistent organic pollutants, and similar hazards. Trade agreements in particular usually specifically exclude measures related to national security from coverage. However, virtually all trade liberalisation agreements promote trade in tobacco products without consideration of public health concerns. This may be because the public health community has not yet significantly engaged in international trade issues and made a compelling political case; or because most nations have not yet begun to regulate effectively tobacco products, and are therefore unlikely to champion international rules. ${ }^{12}$

The FCTC had included in some of its draft versions explicit language that would have given it supremacy over trade rules when conflicts arose. This language was not adopted. However, under standard rules for treaty interpretation, the most recent treaty prevails in conflict negotiations. Decisions implementing the FCTC may thus provide an arena for resolving such conflicts in the interests of health.

\section{CONCLUSION}

As international trade and international financial institutions increasingly influence public health, it is critical that contending priorities be weighed carefully. As governments determine trade and economic policy, there is also a clear need to develop policies that protect human rights, population health, public health systems, and access to vital human

\section{What this paper adds}

Asserting that health is a recognised human right, this article discusses how international trade agreements can prioritise the rights of corporations over health and human rights. The authors discuss how these agreements are negotiated and developed, and show that they can pose threats to tobacco control policies among signatory nations. A pending trade dispute challenges the Master Settlement Agreement that funds significant tobacco control efforts in the USA. The authors advocate for strong actions to protect the health of the public in the face of trade negotiations that threaten to undermine effective tobacco control efforts.

services such as water and sanitation. Any trade-offs should be made only with the greatest thought.

Pollock and Price concluded in their review of the public health implications of world trade negotiations that it is time for an international body with a public health mission such as the WHO to be given the enforcement power to "be a counterweight" to the WTO's trade imperatives. ${ }^{20}$

The International Federation for Human Rights (FIDH) has issued a thorough, strongly worded report condemning international trade agreements because of their effects on human rights. It recommends that "the [UN] Universal Declaration of Human Rights (UDHR) prevails over any trade agreement and that it is incumbent on the WTO as well as on every WTO member state to observe the fundamental principles of human rights. In this respect, the norms set out in the UDHR must be seen as standards." ${ }^{21}$

It will be incumbent upon the public health community to closely monitor events, and strongly advocate for the ascendancy of health over trade, particularly as it applies to tobacco. Tobacco is uniquely deadly and addictive, and should be excluded from all current and future trade agreements. Liberalised trade in tobacco products directly violates human rights as they pertain to health.

Scores of health related organisations and individuals have signed the Call for Public Health Accountability in International Trade Agreements, drafted by the Center for Policy Analysis on Trade and Health, and the list of signatories is growing among public health and tobacco control groups as well as local, state, and national governmental health organisations. ${ }^{22}$ The statement calls on trade representatives and elected officials to:

- Assure that health takes priority over commercial interests

- Call for an assessment of the impact of the GATS and other trade agreements on population health, and assure based on such assessment that these agreements do not have an adverse impact on health

- Exclude vital human services such as health care and water, and intellectual property rules that affect affordable medications, from trade negotiations and challenge under trade agreements

- Include public health representatives in the negotiating advisory process, and promote transparency and democratic accountability at all levels of trade negotiations

- Support enforceable commitments to advancing population health, and to achieving universal access to health care, affordable medications, and safe, affordable water in the USA and internationally.

In sum, in areas where there are conflicts, the human right to health needs to be promoted and protected, even at the cost of the commercial rights of access to markets. 


\section{ACKNOWLEDGEMENTS}

The authors wish to thank John Bloom, Thomas Novotny, Robert Weissman, and Judith Wilkenfeld for information and analysis on US tobacco policy; Alicia Yamin for contributions on human rights and health; and the editors of this supplement to Tobacco Control for their thoughtful review of earlier drafts.

\section{Authors' affiliations}

E R Shaffer, Center for Policy Analysis on Trade and Health, San Francisco, California, USA

J E Brenner, Center for Policy Analysis on Trade and Health, San Francisco, California, USA

T P Houston, Lovisiana State University Health Sciences Center, New Orleans, Lovisiana, USA

Competing interests: none declared

\section{REFERENCES}

1 Griswold DT. Human rights: Globalization and human rights. AWorldConnected. Org, Institute for Humane Studies, George Mason University. http://www.aworldconnected.com/article.php/565.html (Accessed May 22, 2005).

2 United Nations High Commission for Human Rights. Vienna Declaration and Programme of Action, July 12, 1993. http://www.unhchr.ch/huridocda/ huridoca.nsf/(Symbol)/A.CONF. 157.23.En?OpenDocument (Accessed February 19, 2004)

3 United Nations High Commission for Human Rights. International Covenant on Economic, Social, and Cultural Rights (ICESCR), Adopted and opened for signature, ratification and accession by General Assembly resolution 2200A (XXI) of 16 December 1966 entry into force 3 January 1976, in accordance with article 27. Office of the High Commissioner for Human Rights, United Nations. http://www.unhchr.ch/html/menu3/b/a_cescr.htm (Accessed February 19, 2004)

4 World Health Organization. Tobacco and the Rights of the Child. WHO/ NMH/TFI/01.3 World Health Organization, Geneva.

5 Carnegie Endowment for International Peace. NAFTA's promises and realities: lessons from Mexico for the hemisphere. http://www.ceip.org/files/ pdf/NAFTA_Report_ChapterOne.pdf.

6 Chaloupka FJ, Nair R. International issues in the supply of tobacco: recent changes and implications for alcohol. Addiction 2000;(suppl 4):S477-89.

7 Bloom J. Public health, international trade and the framework convention on tobacco control. Campaign for Tobacco-Free Kids. March, 2001. http:// tobaccofreekids.org

8 Callard Cynthia, Collishaw Neil, Swenarchuk Michelle. An introduction to international trade agreements and their impact on public measures to reduce tobacco use. Physicians for a Smoke-Free Canada/Commonwealth Medical
Association. April 2001. http://www.smoke-free.ca/pdf_1/Trade\&TobaccoApril\%202000.pdf.

9 Campaign for Tobacco-Free Kids. Public health and international trade. Volume II: Tariffs and Privatization, Washington, D. C. October 2002. http:// tobaccofreekids.org.

10 Waren WT. Trade Agreement Trade-offs. International trade tribunals challenge state law and policy. State Legislatures, July/August 2004. http:// www.ncsl.org/programs/pubs/SLmag/2004/04SLulAug_Trade.htm.

11 World Trade Organization. Agreement on the Application of Sanitary and Phytosanitary Measures. www.wto.orgp70, 72.

12 Bloom J. Public health, international trade and the framework convention on tobacco control. Campaign for Tobacco-Free Kids. March, 2001. http:// tobaccofreekids.org.

13 American Medical Association. Impact of US tobacco exports on the worldwide smoking epidemic. Report of the Council on Scientific Affairs. June 1989. http://tobaccodocuments.org/ti/TIMN0016471-6513.html?pattern$\% 22$ trade+agreements\%22.

14 General Accounting Office. Trade and health issues: dichotomy between U.S. tobacco export policy and anti-smoking initiatives. GAO/NSAID-90-190. May, 1990.

15 Weissman R. Trade agreement threat to US tobacco Multi State Agreement and other tobacco and health measures. http://lists.essential.org/pipermail/ intl-tobacco/2005ql /001 194.html (Accessed March 6, 2005).

16 Philip Morris. The perspective of Philip Morris International on smoking and health issues. Text of discussion document used at top management meeting. March 29, 1985. Bates Number 2023268329-49. http:// www.pmdocs.com/getallimg.asp?DOCID = 2023268329/8337 Cited in: Hammond R, Howell A, Trust us - we're the tobacco industry.Action on Smoking and Health (UK), Campaign for Tobacco-Free Kids.April 2001.http://tobaccofreekids.org.

17 United Nations. International Covenant on Economic, Social and Cultural Rights. Office of the High Commissioner for Human Rights. Adopted and opened for signature, ratification and accession by General Assembly resolution 2200A (XXI) of 16 December 1966. entry into force 3 January 1976 , in accordance with article 27 . http://www.unhchr.ch/html/menu3/b/ a_cescr.htm.

18 GAO-02-876 International Trade.

19 Agricultural Technical Advisory Committee for Cotton, Peanuts, Planting Seeds and Tobacco. The US-Singapore Free Trade Agreement (FTA) Report of the Agricultural Technical Advisory Committee for Cotton, Peanuts, Planting Seeds and Tobacco. US Trade Representative. February 2003. www.ustr.gov.

20 Pollock AM, Price D. The public health implications of world trade negotiations on the general agreement on trade in services and public services. Lancet 2003;362:1072-5.

21 International Federation for Human Rights. The World Trade Organization and Human Rights. FIDH Position Paper. www. fidh.org (Accessed February 14, 2004).

22 Center for Policy Analysis on Trade and Health. Call for Public Health Accountability in International Trade Agreements. www.cpath.org. 